\title{
Penggunaan Strategi Pembelajaran Modeled Talk untuk Meningkatkan Keterampilan Berbicara Bahasa Inggris Siswa Kelas VIII SMP
}

\author{
Ni Made Meriastuti*
}

SMP Negeri 3 Kubu, Karangasem, Indonesia

\author{
A R T I C L E I N F O \\ Article history: \\ Received 19 Maret 2018 \\ Received in revised form \\ 25 Maret 2018 \\ Accepted 10 April 2018 \\ Available online 25 Mei \\ 2018 \\ Kata Kunci: \\ Strategi pembelajaran, \\ Modeled Talk, \\ Keterampilan Berbicara \\ Keywords: \\ Learning strategy, Modeled \\ Talk, Speaking Skills
}

A B S T R A K
Penelitian ini dilatarbelakangi oleh kemampuan siswa kelas VIII
SMP dalam belajar bahasa Inggris masih kurang khususnya dalam
keterampilan berbicara. Penelitian ini bertujuan untuk meningkatkan
keterampilan berbicara bahasa Inggris siswa kelas VIII SMP dengan
menggunakan Modeled Talk. Metode yang digunakan untuk
mengumpulkan data adalah metode tes dan observasi. Adapun
instrumen yang digunakan dalam pengumpulan data adalah tes, lembar
observasi dan angket atau kuesioner. Hasil penelitian ini menunjukkan
ada peningkatan keterampilan berbicara bahasa Inggris siswa, di mana
pada siklus I rata-rata nilai keterampilan berbicara siswa sebesar 2.75
dengan prosentase $64.2 \%$ dan pada siklus II rata-rata nilai keterampilan
berbicara siswa sebesar 3.00 dengan prosentase $70.0 \%$ dan termasuk
kategori baik. Dilihat dari 5 (lima) aspek keterampilan berbicara yang
dinilai yaitu pelafalan, tata bahasa, kosakata, kelancaran dan
pemahaman juga mengalami peningkatan dari siklus I ke siklus II. Pada siklus I, prosentase untuk pelafalan $65.8 \%, 65.8 \%$ untuk tata bahasa, $68.3 \%$ untuk kosakata, $60.0 \%$ untuk kelancaran, dan $60.8 \%$ untuk pemahaman. Selanjutnya pada siklus II terjadi peningkatan pada masing-masing aspek yaitu pelafalan sebesar $70.8 \%$, tata bahasa sebesar $72.5 \%$, kosakata sebesar $69.2 \%$, kelancaran sebesar $67.5 \%$ dan $70.0 \%$ untuk aspek pemahaman. Ketuntasan secara klasikal di siklus I hanya $64.3 \%$ siswa yang mampu memperoleh nilai sama dengan atau lebih besar dari nilai KKM yaitu 67. Selanjutnya disiklus II terjadi peningkatan untuk ketuntasan klasikal yaitu menjadi 89.3\%. Dengan demikian, penggunaan Modeled Talk dapat meningkatkan keterampilan berbicara bahasa Inggris siswa kelas VIII SMP.

\section{A B S T R A C T}

This research was motivated by the ability of grade VIII students of junior high school in learning English was still low especially in speaking skill. This study aims to improve English speaking skill of grade VIII students of junior high school by using Modeled Talk. The method used to collect data was the method of test and observation. The instruments used in data collection were test, observation sheet and questionnaire. The results of this study indicated that there was an improvement in students' speaking skill, in which on the first cycle of this study the average score of the students' speaking skill was 2.75 with the percentage of $64.2 \%$ and on the second cycle the average score of students' speaking skill was 3.00 with percentage of $70.0 \%$ and the category was good. According to five aspects of speaking skill assessed namely pronunciation, grammar, vocabulary, fluency and comprehension increased from the first cycle to the second cycle. In cycle 1 , the percentage of pronunciation was $65.8 \%, 65.8 \%$ for grammar, $68.3 \%$ for vocabulary, $60.0 \%$ for fluency and $60.8 \%$ for comprehension. Furthermore in cycle 2, there was an increase in each aspect such as: pronunciation of $70.8 \%$, grammar of $72.5 \%$, vocabulary of $69.2 \%$, fluency of $67.5 \%$ and $70.0 \%$ for comprehension aspect. The classical completeness of cycle 1 was $64.3 \%$ of students who were able to get the score equal to or more than 67 as the minimum criterion score. Furthermore, in cycle 2 occurred an increase for classical completeness that was $89.3 \%$. Thus, the application of Modeled Talk can improve the English speaking skill of grade VIII junior high school students.

Copyright (C) Universitas Pendidikan Ganesha. All rights reserved. 


\section{Pendahuluan}

Pengajaran Bahasa Inggris sebagai bahasa asing melibatkan 4 (empat) keterampilan dasar, salah satunya adalah keterampilan bicara. Mengajarkan bicara bukanlah hanya sekedar mendorong peserta didik untuk berbicara menggunakan bahasa inggris. Berbicara adalah sebuah proses antara pembicara dan pendengar dimana mereka seharusnya mengerti satu sama lain atau mendapatkan arti dari apa yang mereka ucapkan. Huda (1999) mengatakan bahwa seseorang dikatakan memiliki kompetensi berkomunikasi apabila dia bisa menggunakan bahasa dengan gaya yang sesuai dengan situasi. Hal tersebut mengggambarkan bahwa berbicara seharusnya mendapat prioritas dalam pengajaran bahasa Inggris, agar peserta didik mampu menggunakan bahasa Inggris secara oral.

Penulis menemukan banyak peserta didik yang mengalami kesulitan dalam belajar bahasa Inggris terutama dalam bicara menggunakan bahasa Inggris. Menurut pengamatan penulis sekaligus pengajar di kelas VIII E, sebagian besar peserta didik mengalami masalah dalam belajar bahasa Inggris terutama untuk kemampuan berbicara. Mereka hanya mampu bicara dan mengerti beberapa kata-kata yang umum seperti: how are you, thank you, yes, no, dan beberapa kalimat yang sering diucapkan setiap kali pembelajaran bahasa Inggris berlangsung. Kebanyakan dari peserta didik bisa mengucapakan kata-kata bahasa Inggris tersebut karena mereka biasa mengucapkannya dan meghapalkannnya.

Untuk itu, sebuah tes diadakan untuk menemukan masalah utama peserta didik dalam berbicara bahasa Inggris. Peserta didik di kelas VIII E diminta untuk memperkenalkan diri satu per satu didepan kelas secara singkat. Dari hasil Observasi Awal bisa diamati bahwa kemampuan berbicara kelas VIII E sangat kurang. Total nilai rata-rata 2.51 dan presentase nilainya adalah 58.7\%. Presentase nilai tersebut menunjukkan tidak tuntas. Dari hasil Observasi Awal, hanya 8 (delapan) orang siswa yang mampu memperoleh nilai sama dengan atau diatas KKM yaitu 67. Hanya $28.6 \%$ siswa yang memiliki kemampuan berbicara yang bagus. Dengan demikian bisa disimpulkan bahwa sebagian besar siswa memiliki kemampuan berbicara yang kurang disebabkan oleh (1) keterbatasan kosakata, (2) sering salah melafalkan kata, dan (3) mereka memiliki pengetahuan yang terbatas tentang tata bahasa. Selanjutnya, masalah pemahaman dan kurangnya motivasi siswa dalam belajar bahasa Inggris juga ditemukan pada sebagian besar siswa khususnya di kelas VIII E.

Selain hal tersebut diatas, permasalahan lain yang terjadi adalah sebagian besar siswa merasa bosan dan kurang antusias ketika guru menjelaskan topik atau materi. Sebagai contohnya, ketika siswa belajar tentang teks naratif dan guru akan meminta siswa bermain peran (role play) sebagai penilaian unjuk kerja atau praktik sedangkan siswa sebenarnya mungkin belum mengerti tentang topik atau materi. Sebagai hasilnya, mereka hanya menghapalkan tanpa benar-benar mengerti maksud yang dibicarakan. Hal tersebut bisa memicu kurangnya antusias siswa dalam mengikuti pembelajaran bahasa Inggris terutama ketika kelas speaking berlangsung.

Mempertimbangkan masalah-masalah yang ditemukan penulis selama mengajar bahasa Inggris, menggunakan strategi pembelajaran inovatif adalah cara terbaik untuk mengatasi permasalahan tersebut. "Modeled Talk" adalah salah satu srategi pembelajaran yang bisa digunakan untuk meningkatkan kemampuan berbicara siswa dalam bahasa Inggris.

Seperti yang dikutip Bailey dari Florez (1991), berbicara adalah proses interaksi untuk membangun arti yang melibatkan menghasilkan dan menerima dan memproses informasi. Berbicara juga diartikan sebagai adalah suatu alat untuk mengkomunikasikan gagasan-gagasan yang disusun serta dikembangkan sesuai dengan kebutuhan-kebutuhan pendengar atau penyimak (Tarigan, 2008:16-17). Selain itu, Arsjad dan Mukti U.S (1991:17) memberikan pengertian bahwa kemampuan berbicara adalah kemampuan mengucapkan bunyi-bunyi artikulasi atau mengucapkan kata-kata untuk mengekspresikan, menyatakan, menyampaikan pikiran, gagasan dan perasaan. Menurut Nurgiyantoro (2001:276) berbicara adalah aktivitas berbahasa kedua dilakukan manusia dalam kehidupan berbahasa yaitu setelah aktivitas mendengarkan.

Keterampilan berbicara dalam mempelajari bahasa Inggris adalah keterampilan yang sangat penting. Keterampilan berbicara sangat erat kaitannya dengan keterampilan berkomunikasi. Komunikasi adalah suatu proses atau kegiatan penyampaian pesan dari seseorang kepada orang lain untuk mencapai tujuan tertentu. Selanjutnya, Susanto (1974) mendefinisikan kalau proses komunikasi adalah sebuah proses mengirim dan menerima simbul-simbul yang berarti. Prinsip dasar dari sebuah komunikasi yang sukses adalah pengirim (sender/ encoder) dan penerima (receiver/ decoder) mengerti pesan yang sama dari komunikasi tersebut.

Dengan demikian dapat disimpulkan bahwa keterampilan berbicara sangat penting dimiliki siswa dalam mempelajari bahasa khususnya bahasa Inggris. Sehingga apa yang dipelajari, mereka benar-benar memahaminya sehingga mereka bisa mengkomunikasikannya. Siswa harus memahami kalau 
keterampilan berbicara bahasa Inggris tidak cukup dengan mampu memperagakan dialog didepan kelas kemudian selesai ketika kelas bahasa Inggris berakhir.

Selanjutnya, Modeled Talk adalah salah satu strategi pembelajaran yang bisa digunakan untuk meningkatkan keterampilan berbicara. Herrel (1999) menyatakan bahwa Modeled Talk adalah salah satu strategi mengajar yang sangat sederhana dan kuat. Konsep dari metode ini adalah menggambarkan sebuah ide, sebuah konsep baru, atau istilah baru dengan menggunakan gerak tubuh, gambar visual dan demontrasi sebagai penjelasan. Gerak tubuh dan contoh-contoh bisa membuat siswa tahu apa yang harus dilakukan. Dengan menunjukkan atau memberi model ketika berbicara, siswa akan memiliki gambaran yang jelas tentang sebuah ide, istilah baru, atau konsep dalam bahasa Inggris yang diperkenalkan oleh guru. Adapun tujuan penelitian tindakan ini adalah untuk meningkatkan keterampilan berbicara siswa kelas VIII dengan menggunakan strategi pembelajaran Modeled Talk.

\section{Metode}

Peneliti menggunakan Penelitian Tindakan Kelas (PTK) untuk penelitian ini. Hal ini disebabkan oleh peneliti bertujuan mengadakan penelitian meningkatkan keterampilan berbicara siswa. Subyek penelitian ini adalah siswa kelas VIII SMP Negeri $3 \mathrm{Kubu}$, khususnya kelas VIII E. Jumlah siswa adalah 28 orang yang terdiri dari 14 orang perempuan dan 14 orang laki-laki. Sementara itu, objek dalam penelitian ini adalah keterampilan berbicara bahasa Inggris kelas VIIIB SMP Negeri 3 Kubu. Variabel dalam penelitian ini adalah Modeled Talk dan keterampilan berbicara bahasa Inggris siswa. Oleh karena itu, peningkatan keterampilan berbicara bahasa Inggris siswa akan bergantung kepada penggunaan strategi pembelajaran Modeled Talk.

Prosedur penelitian yang dilakukan meliputi : (1) refleksi awal, peneliti mengkaji permasalahan yang dihadapi siswa yang menyebabkab keterampilan berbicara siswa termasuk kategori kurang atau lemah; (2) rencana tindakan; (3) pelaksanaan tindakan; (4) observasi dan evaluasi, dan (5) refleksi, peneliti melaksanakan kegiatan ini setelah pelaksanaan observasi dan evaluasi dan refleksi dilaksanakan untuk mengidentifikasi keberhasilan dan ketidakberhasilan dari tindakan.

Untuk memperoleh data tentang penelitian ini ada beberapa instrumen yang digunakan yaitu observasi dan tes. Dalam mengadakan penelitian pada tahap awal, peneliti menggunakan sebuah observasi awal. Observasi awal diadakan untuk mengetahui masalah sebenarnya yang dialami oleh siswa. Tes terdiri dari observasi awal dan tes akhir. Observasi awal digunakan untuk mengetahui keterampilan berbicara siswa sebelum menggunakan tehnik yang akan diterapkan. Sedangkan tes akhir bertujuan untuk mengukur keterampilan berbicara siswa setelah tehnik diterapkan. Tes yang digunakan adalah tes berbicara yang digunakan oleh peneliti untuk menilai keterampilan berbicara siswa. Lembar observasi dipersiapkan untuk mengetahui dan mengamati keterampilan berbicara siswa pada saat observasi awal dan tes akhir. Bentuk lembar observasi adalah sebagai berikut:

Tabel 1. Lembar Observasi Penilaian 'Speaking'

\begin{tabular}{|c|c|c|c|c|c|c|c|c|c|c|}
\hline \multirow[b]{2}{*}{ No } & \multirow[b]{2}{*}{ Nama } & \multicolumn{5}{|c|}{ Indikator } & \multirow[b]{2}{*}{$\begin{array}{c}\text { Tot } \\
\text { al }\end{array}$} & \multirow[b]{2}{*}{$\begin{array}{c}\mathrm{Nil} \\
\mathrm{ai}\end{array}$} & \multirow[b]{2}{*}{$\begin{array}{c}\text { Kategor } \\
\text { i }\end{array}$} & \multirow[b]{2}{*}{ Ket } \\
\hline & & $\begin{array}{l}\text { Pelaf } \\
\text { alan } \\
(1-4)\end{array}$ & $\begin{array}{c}\text { Tata } \\
\text { bahasa } \\
(1-4)\end{array}$ & $\begin{array}{c}\text { Kosakat } \\
\text { a } \\
(1-4) \\
\end{array}$ & $\begin{array}{c}\text { Kelanca } \\
\text { ran } \\
(1-4)\end{array}$ & $\begin{array}{l}\text { Pemah } \\
\text { aman } \\
(1-4)\end{array}$ & & & & \\
\hline
\end{tabular}

Untuk mengetahui keterampilan berbicara siswa, ada kriteria penilaian yaitu berupa rubrik untuk penilaian keterampilan berbicara yaitu: 
Tabel 2. Rubrik Penilaian 'Speaking'

Dalam penelitian ini, peneliti juga menggunakan angket atau kuesioner sebagai instrumen penelitian.

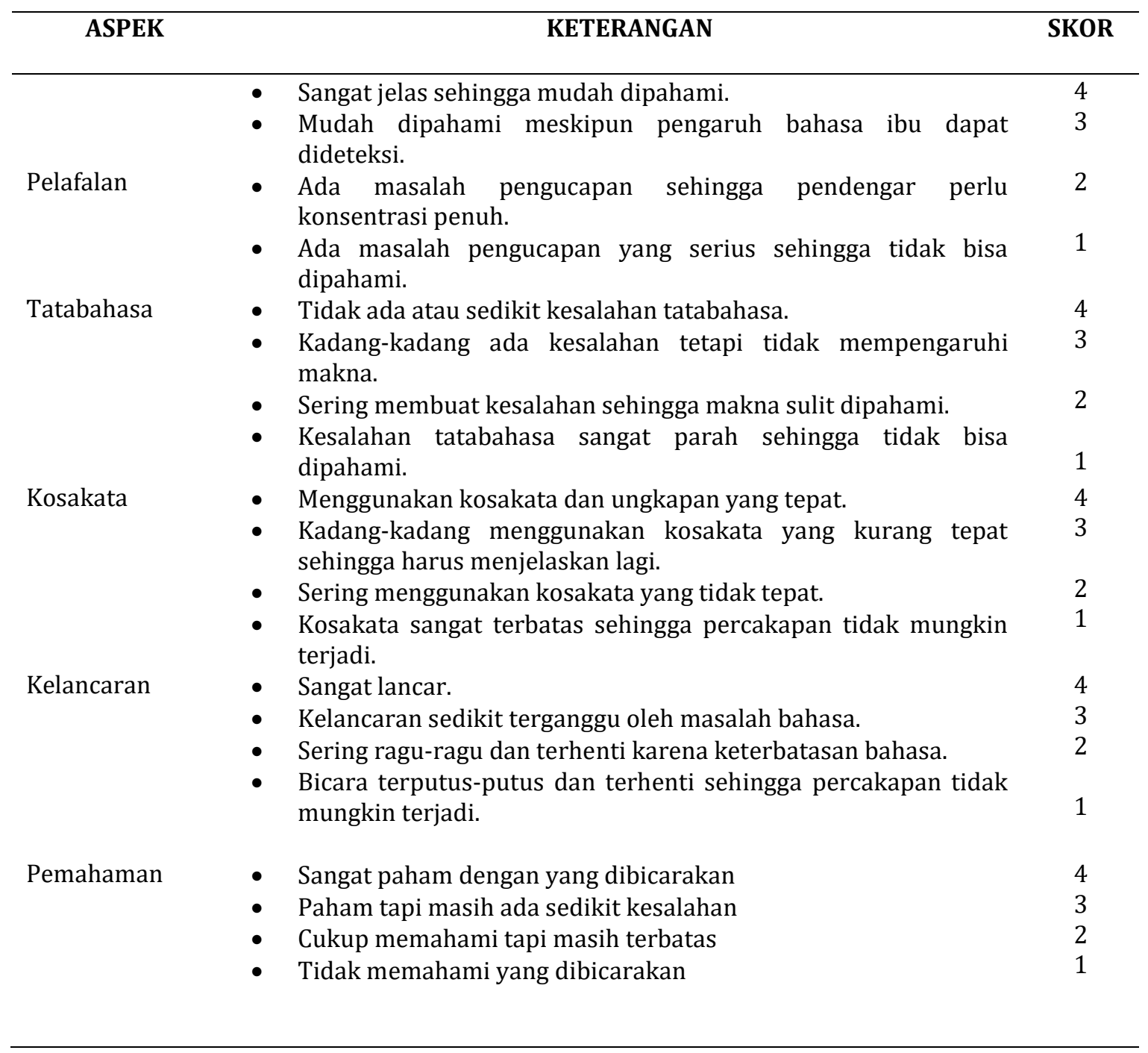

Angket saat observasi awal diberikan dengan tujuan untuk mengetahui permasalahan yang dialami siswa terutama dalam keterampilan berbicara. Angket saat tes akhir atau ketika siklus terakhir diberikan dengan tujuan untuk mengetahui tanggapan siswa terhadap penggunaan Modeled Talk untuk meningkatkan keterampilan berbicara mereka.

Dalam penelitian ini ada dua jenis data yang akan dikumpulkan. Data tersebut adalah data kualitatif dan kuantitatif. Data kualitatif diambil dari angket atau kuesioner. Data dianalisis secara deskriptif. Data yang diperoleh dari angket akan menjadi kualitatif data. Jawaban siswa akan dihitung menjadi presentase dan hasilnya akan dijelaskan dengan rinci. Presentase akan dihitung dengan menggunakan rumus:

$\%=$ \umlah pilihan siswa $\times 100 \%$ Jumlah siswa

Data kuantitatif diambil dari lembar observasi. Data yang diperoleh akan dianalisis secara deskriptif. Rumus yang digunakan untuk menganalisis data adalah sebagai berikut : 
Rumus untuk memperoleh nilai rata-rata siswa

$$
\begin{aligned}
& \bar{X}=\frac{\sum X}{N} \\
& \text { Catatan: } \\
& \bar{X} \quad=\text { Nilai rata-rata } \\
& \sum X \quad=\text { Skor keseluruhan yang diperoleh } \\
& \mathrm{N} \quad=\text { Total nilai keseluruhan siswa }
\end{aligned}
$$

- $\quad$ Presentase nilai rata-rata siswa

$$
\text { - } \quad \begin{aligned}
& \text { Presentase siswa }=\frac{\text { Nilai yang diperoleh }}{\text { Nilai maksimal }} \text { Presentase siswa yang memperoleh nilai standar } \\
& \text { Prom }
\end{aligned}
$$

$$
\begin{aligned}
& \%=\frac{\text { Jumlah siswa yang mencapai nilai standar X } 100 \%}{\text { Jumlah siswa keseluruhan }} \\
& \text { Tingkat penguasaan keterampilan berbicara siswa }
\end{aligned}
$$

Tabel 3. Tingkat Penguasaan Keterampilan Berbicara Siswa

\begin{tabular}{cl}
\hline Interval skor & \multicolumn{1}{c}{ Kategori } \\
\hline $90-100 \%$ & Amat Baik (Excelent) \\
$80-89 \%$ & Sangat Baik (Very good) \\
$70-79 \%$ & Baik (Good) \\
$60-69 \%$ & Cukup (Sufficient) \\
$0-59 \%$ & Kurang (Insufficient) \\
\hline & Harahap (1982) dalam Hariprawani (2002)
\end{tabular}

Penelitian dikatakan berhasil apabila ketuntasan secara klasikal tercapai yaitu minimal $85 \%$ dari jumlah siswa keseluruhan memperoleh nilai minimal 67.

\section{Hasil dan Pembahasan}

\section{Hasil}

Angket atau kuesioner pertama dalam penelitian ini dibagikan saat observasi awal. Dari hasil angket, peneliti menemukan $92.86 \%$ siswa kelas VIII E mengakui jarang berbicara dalam bahasa Inggris, 82.14\% siswa tidak merasa senang ketika diminta untuk berbicara menggunakan bahasa Inggris didepan kelas dan $\mathbf{8 5 . 7 1 \%}$ siswa merasa tidak siap ketika diminta berbicara didepan kelas. Alasan ketidaksiapan siswa yaitu $14.29 \%$ siswa merasa ragu-ragu dan takut untuk kedepan, 17.86\% mengaku tidak bisa menghapal dialog, 25\% siswa menyebutkan tidak mengerti topik, dan 30.0\% siswa tidak punya kosakata bahasa Inggris yang banyak. Selanjutnya dari hasil angket, peneliti juga menemukan bahwa hanya 14.29\% siswa menyukai tehnik pengajaran untuk keterampilan berbicara yang sudah digunakan, dan hanya 39.29\% siswa menyukai cara guru menjelaskan materi untuk pelajaran speaking. Selain itu, 67.86\% siswa mengatakan tidak pernah diberikan contoh bercakap-cakap dan $82.14 \%$ siswa menyebutkan kalau guru menterjemahkan kata-kata sulit ke bahasa Indonesia. Dari hasil angket peneliti menemukan 75\% siswa mengatakan guru tidak menggunakan media dalam mengajarkan bahasa Inggris.

Berikut ini adalah hasil proentase nilai rata-rata keterampilan berbicara siswa dalam observasi awal dapat dilihat pada Tebal 4. 
Tabel 4. Prosentase Nilai Rata-rata keterampilan berbicara siswa dalam Observasi Awal

\begin{tabular}{|c|c|c|c|}
\hline $\begin{array}{l}\text { Indikator Keterampilan berbicara yang } \\
\text { dinilai }\end{array}$ & Rata-rata & Prosentase & Kategori \\
\hline Pelafalan & 2.43 & $56.7 \%$ & Cukup \\
\hline Tata bahasa & 2.75 & $64.2 \%$ & Cukup \\
\hline Kosa-kata & 2.75 & $64.2 \%$ & Cukup \\
\hline Kelancaran & 2.36 & $55.0 \%$ & Kurang \\
\hline Pemahaman & 2.29 & $53.3 \%$ & Kurang \\
\hline Total rata-rata & 2.51 & $58.7 \%$ & Kurang \\
\hline
\end{tabular}

Tabel diatas menunjukkan keterampilan berbicara siswa secara umum. Prosentase keterampilan berbicara siswa secara umum menunjukkan 58.7\% dan tergolong kurang. Dari keseluruhan siswa kelas VIII E yang mengikuti observasi awal hanya $28.6 \%$ siswa yaitu 8 orang siswa yang memperoleh nilai sama dengan atau lebih dari nilai KKM yaitu 67.

Selanjutnya, peneliti menggunakan strategi pembelajaran Modeled Talk pada siklus I dan memberikan tes berbicara kepada siswa berkaitan dengan materi yang diajarkan. Hasil prosentase nilai rata-rata keterampilan berbicara siswa pada tes siklus I dapat dilihat pada Tabel 5.

Tabel 5. Prosentase Nilai Rata-rata keterampilan berbicara siswa dalam Tes Siklus I

\begin{tabular}{|c|c|c|c|}
\hline Indikator Keterampilan berbicara yang dinilai & Rata-rata & Prosentase & Kategori \\
\hline Pelafalan & 2.82 & $65.8 \%$ & Cukup \\
\hline Tata bahasa & 2.82 & $65.8 \%$ & Cukup \\
\hline Kosa-kata & 2.93 & $68.3 \%$ & Cukup \\
\hline Kelancaran & 2.57 & $60.0 \%$ & Cukup \\
\hline Pemahaman & 2.61 & $60.8 \%$ & Cukup \\
\hline Total rata-rata & 2.75 & $64.2 \%$ & Cukup \\
\hline
\end{tabular}

Selanjutnya, peneliti membagikan angket atau kuesioner pada akhir siklus I untuk mengetahui tanggapan siswa terhadap strategi pembelajaran yang digunakan. Hasilnya menunjukkan bahwa $71.43 \%$ siswa menyukai tehnik yang digunakan dan $78.57 \%$ siswa mengatakan kalau media (gambar, caption) yang digunakan bisa membantu mereka dalam mengerti materi. Ada 89.29\% siswa mengatakan bahwa gesture atau gerak-isyarat (mimik, ekspresi muka, dan gerakan tubuh) yang digunakan oleh guru bisa membantu mereka untuk memahami materi atau topik speaking yang diajarkan, dan $92.86 \%$ siswa mengakui bahwa contoh bercakap-cakap atau berbicara dari guru membantu mereka dalam memahami topik atau materi speaking. Dari hasil angket, 85.71\% siswa mengakui kalau gestures atau gerak isyarat yang digunakan bisa mendukung penjelasan materi. Selanjutnya $64.29 \%$ siswa mengakui bahwa contoh bercakap-cakap atau berbicara yang ditunjukkan oleh guru tidak sulit dimengerti dan 78.57\% mengakui kalau tehnik yang digunakan tidak membuat mereka bosan. Ada 82.14\% siswa yang mengakui kalau tehnik yang digunakan membuat mereka siap untuk berbicara bahasa Inggris dan 89.29\% siswa mengatakan kalau mereka menjadi lebih senang dalam belajar bahasa Inggris khususnya berbicara dikarenakan tehnik yang dipergunakan oleh guru.

Berdasarkan hasil tes siklus 1 penelitian belum bisa dinyatakan berhasil secara klasikal sehingga dilanjutkan ke siklus II. Hasil prosentasi nilai berbicara siswa di siklus II dapat dilihat pada Tebal 6.

Tabel 6. Prosentase Nilai Rata-rata keterampilan berbicara siswa dalam Tes Siklus II

\begin{tabular}{|c|c|c|c|}
\hline Indikator Keterampilan berbicara yang dinilai & Rata-rata & Prosentase & Kategori \\
\hline Pelafalan & 3.04 & $70.8 \%$ & Baik \\
\hline Tata bahasa & 3.11 & $72.5 \%$ & Baik \\
\hline Kosa-kata & 2.96 & $69.2 \%$ & Cukup \\
\hline Kelancaran & 2.89 & $67.5 \%$ & Cukup \\
\hline Pemahaman & 3.00 & $70.0 \%$ & Cukup \\
\hline Total rata-rata & 3.00 & $70.0 \%$ & Baik \\
\hline
\end{tabular}


Dari tabel diatas, ditunjukkan bahwa keterampilan berbicara siswa termasuk kategori baik. Total prosentase menunjukkan keterampilan siswa dalam berbicara secara umum. Hasil keterampilan berbicara siswa yang dijelaskan dengan menunjukkan tingkat penguasaan menunjukkan adanya peningkatan. Prosentase kemampuan berbicara siswa saat tes siklus I adalah $64.3 \%$ dan menunjukkan tingkat penguasaan yang cukup. Sedangkan pada tes siklus II, prosentase kemampuan siswa adalah $70.0 \%$ dan termasuk kategori baik. Prosentase kemampuan siswa meningkat 5.8. Itu menunjukkan adanya peningkatan kemampuan siswa pelaksanaan tindakan yaitu penggunaan Modeled Talk yang dilakukan oleh peneliti di kelas VIIIE.

Selanjutnya, peneliti kembali membagikan angket atau kuesioner pada akhir siklus II. Hasilnya menunjukkan bahwa 92.86\% siswa menyukai tehnik yang digunakan, $89.29 \%$ siswa mengatakan kalau media (gambar, caption) yang digunakan bisa membantu dalam mengerti materi, 96.43\% siswa mengatakan bahwa gesture atau gerak-isyarat (mimik, ekspresi muka, dan gerakan tubuh) juga membantu mereka untuk memahami materi atau topik speaking yang diajarkan, $92.86 \%$ siswa mengakui bahwa contoh bercakap-cakap atau berbicara dari guru membantu mereka dalam memahami topik atau materi speaking dan $85.71 \%$ siswa mengakui kalau gestures atau gerak isyarat yang digunakan oleh guru bisa mendukung penjelasan materi. $82.14 \%$ siswa mengakui bahwa contoh bercakap-cakap atau berbicara yang ditunjukkan oleh guru tidak sulit dimengerti. 85.71\% mengakui kalau tehnik yang digunakan tidak membuat mereka bosan. Ada $85.71 \%$ siswa yang mengakui kalau tehnik yang digunakan membuat mereka siap untuk berbicara bahasa Inggris dan $96.43 \%$ siswa mengatakan kalau mereka menjadi lebih senang dalam belajar bahasa Inggris dikarenakan tehnik yang dipergunakan oleh guru.

\section{Pembahasan}

Berdasarkan hasil pengamatan, bisa disimpulkan bahwa penggunaan Modeled Talk bisa meningkatkan keterampilan berbicara siswa.

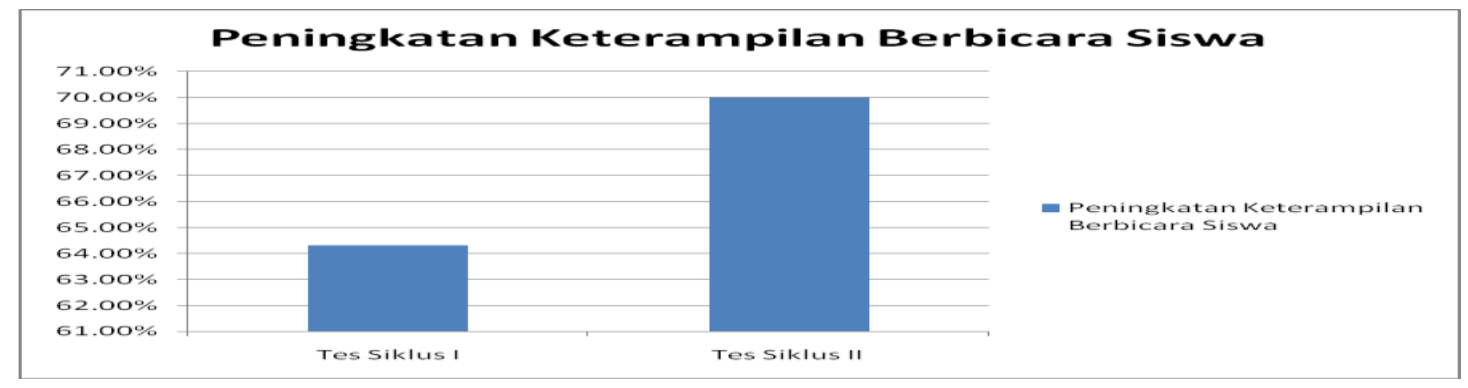

Grafik 1. Prosentase Nilai Rata-rata Siswa dalam Keterampilan Berbicara

Grafik 1 menunjukkan bahwa keterampilan berbicara siswa meningkat dari tes siklus I dan ke tes siklus II. Kemampuan berbicara siswa telah meningkat dari $64.2 \%$ termasuk kategori cukup pada test siklus I menjadi $70.0 \%$ pada tes siklus II dan termasuk kategori baik. Ini juga menunjukkan penggunaan Modeled Talk bisa meningkatkan keterampilan berbicara siswa.

Peneliti juga menganalisis kemampuan berbicara siswa menurut 5 (lima) aspek atau indikator keterampilan berbicara yaitu pelafalan, tata bahasa, kosakata, kelancaran dan pemahaman. Ada peningkatan keterampilan berbicara siswa dalam 5 aspek tersebut dari tes siklus I sampai tes siklus II. Peningkatan prosentase nilai rata-rata siswa dalam aspek pelafalan, tata bahasa, kosakata, kelancaran dan pemahaman bisa digambarkan dalam grafik berikut ini:

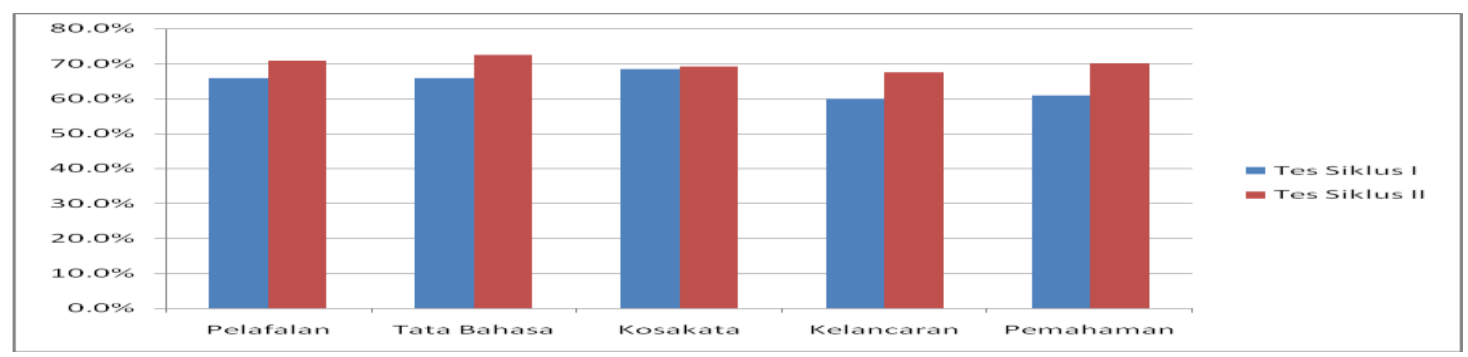

Grafik 2. Prosentase Nilai Rata-rata Siswa dalam Aspek Pelafalan, Tata bahasa, Kosakata, Kelancaran, dan Pemahaman 
Berdasarkan grafik 2, bisa disimpulkan bahwa prosentase nilai rata-rata siswa dalam aspek pelafalan, tata bahasa, kosa kata, kelancaran dan pemahaman sudah meningkat dari tes siklus I sampai tes siklus II. Untuk pelafalan prosentase nilai rata-rata siswa sudah meningkat dari kategori cukup pada post test I menjadi baik pada tes siklus II. Untuk tata bahasa 65.8\% (Cukup) pada tes siklus I dan 72.5\% (Baik) pada tes siklus II. Selain itu untuk aspek kosa kata, prosentase nilai rata-rata siswa juga menunjukkan peningkatan yaitu dari 68.3\% tergolong kategori cukup menjadi 69.2\% masih termasuk kategori baik. Untuk kelancaran, pencapaian siswa juga meningkat dari $60.0 \%$ menjadi $67.5 \%$. Prosentase untuk pemahaman juga meningkat dari $60.8 \%$ yang tergolong baik menjadi $70.0 \%$ termasuk kategori baik.

Selanjutnya peneliti juga menemukan kalau jumlah siswa yang mencapai nilai $\geq 67$ meningkat dari observasi awal sampai tes siklus II. Perbandingan jumlah siswa yang memperoleh nilai standar dapat dilihat pada grafik berikut:

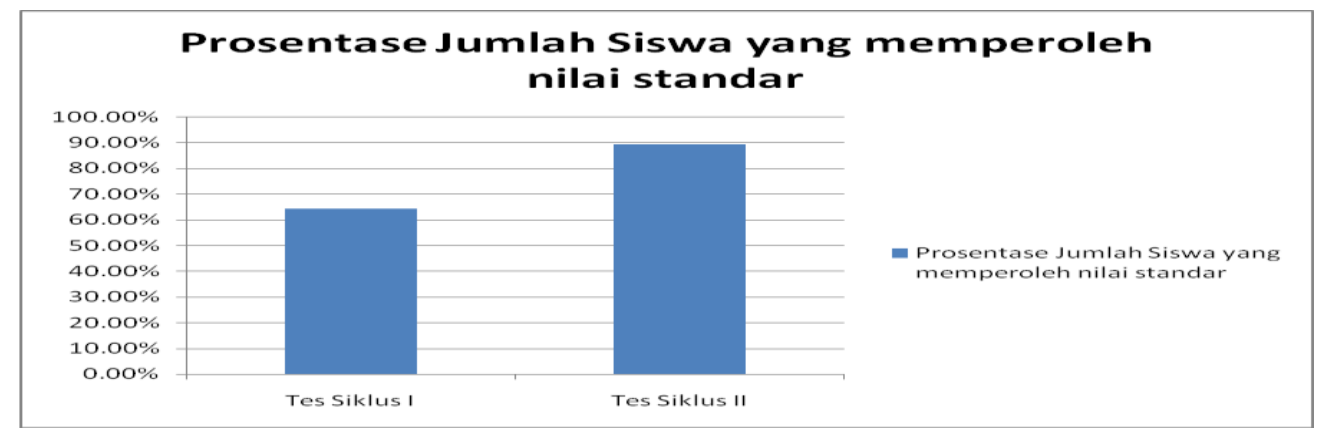

Grafik 3 Peningkatan Prosentase Siswa yang Memperoleh Nilai Standar

Grafik diatas menunjukkan dengan jelas kalau jumlah siswa yang memperoleh nilai standar atau nilai $\geq 67$ telah meningkat. Jumlah siswa yang memperoleh nilai standar pada tes siklus I 64.3\% dan 89.3\% pada tes siklus II. Itu menunjukkan peningkatan siswa dalam mencapai nilai sama dengan atau lebih dari 67. Selanjutnya, berdasarkan hasil dari tes siklus II, penelitian ini dianggap berhasil karena sudah mampu mencapai indikator keberhasilan yaitu lebih dari 85\% siswa bisa mencapai nilai sama dengan atau lebih dari nilai KKM yaitu 67.

Berdasarkan hasil angket atau kuesioner pada akhir siklus I dan II, bisa dikatakan bahwa siswa cukup merasa terbantu dengan penggunaan Modeled Talk sebagai strategi mengajar dalam meningkatkan keterampilan berbicara mereka. Siswa memberi banyak perhatian ketika guru menjelaskan materi atau topik untuk speaking. Mereka menyukai dan merasa terbantu dengan media yang digunakan seperti gambar-gambar yang berhubungan dengan topik yang diajarkan. Gambar-gambar yang digunakan menjadi obyek yang menarik untuk diamati oleh siswa ketika guru menggunakannya sebagai contoh atau rangsangan untuk komentar siswa. Selain itu, ada banyak siswa yang mengakui kalau gerak isyarat yang digunakan guru ketika menjelaskan materi bisa mendukung penjelasan dan contoh bercakap-cakap atau berbicara banyak membantu siswa dalam mengurangi keragu-raguan mereka untuk berbicara dalam bahasa Inggris.

Modeled Talk bisa meminimalisasi keragu-raguan siswa untuk berbicara karena media dan gerakisyarat membantu mereka dalam memahami materi dan memberi model berbicara bisa menjadi contoh bagaimana berbicara bahasa Inggris. Hal itu sangat berguna untuk siswa. Tehnik ini tidak fokus kepada keaktifan partisipasi siswa tetapi untuk membantu siswa agar siap sebelum diminta untuk menunjukkan kemampuan berbicara mereka. Ada banyak siswa yang mengakui kalau penggunaan tehnik membuat mereka lebih siap untuk berbicara dan lebih senang dalam belajar bahasa Inggris khususnya untuk kegiatan keterampilan berbicara

\section{Simpulan Dan Saran}

Berdasarkan hasil dan pembahasan yang disajikan di bab IV, bisa disimpulkan bahwa penggunaan Modeled Talk bisa meningkatkan keterampilan berbicara siswa khususnya siswa kelas VIII E di SMP Negeri 3 Kubu. Ini bisa dilihat dari peningkatan prosentase nilai rata-rata siswa pada masing-masing siklus. Prosentase nilai rata-rata siswa pada Observasi Awal Kemampuan berbicara siswa telah meningkat dari 58.7\% dalam Observasi Awal dan termasuk kategori kurang menjadi $64.2 \%$ pada Tes Siklus I dan tergolong cukup kemudian meningkat menjadi 70.0\% yang termasuk kategori baik. Ini juga menunjukkan penggunaan tehnik Modeled Talk bisa meningkatkan kemampuan berbicara siswa. 
Berdasarkan hasil penelitian ini, disarankan agar Modeled Talk bisa efektif untuk digunakan, disarankan agar menggunakan tehnik ini untuk mengajarkan speaking untuk siswa Sekolah Menengah Pertama (SMP) dan siswa sekolah dasar. Hal itu karena siswa SD dan SMP membutuhkan banyak contoh berbicara sebelum memperlihatkan atau menunjukkan keterampilan berbicara mereka. Dalam memahami materi, siswa untuk tingkat tersebut memerlukan lebih dari sekedar penjelasan dan praktik. Guru harus bisa mengkombinasi media, gesture dan demonstrasi untuk mendukung penjelasan. Itu bisa membantu siswa untuk memahami materi dengan baik tanpa rasa kebosanan dalam kelas bahasa Inggris.

\section{Daftar Rujukan}

Arends, Richard I. 1997. Classroom Instructional and Management. McGraw-Hill Companies, Inc. United States.

Bailey, Kathleen M. 2005. Practical English Language Teaching: Speaking. McGraw-Hill. Singapore.

Cross, D. 1991. A Practical Handbook of Language Teaching.

Hariprawani, Made M. 2002. Improving the Participation and the Achievement of the First Year Students of SMK N 1 Singaraja in Speaking Class through question and Answer technique in Academic year of 2001/2002. Unpublished Thesis. IKIP Negeri Singaraja.

Herrel, A. 2005. Fifty Strategies for Teaching English Language Learners.

Howden, B.J. 1998. Using action research to enhance the teaching of writing. Quenssland Journal of Education Research, 14(1), 45-58. http://education.curtin.edu.au//iier/qjer/qjer14/howden.html.

Huda, N. 1999. Language Learning and Teaching. IKIP Malang.

Lee, James F. And VanPatten, B. 2003. Making Communicative Language Teaching Happens. McGraw-Hill Companies, Inc. United States.

Saputra, Irmawan Hadi. 2013. Pengertian Data Kuantitatif dan Kualitatif. Diakses pada tanggal 26 Desember2014. $\quad$ http://www.plengdut.com/2013/08/ Pengertian-Data-Kuantitatif-danKualitatif.html.

Susanto, Dr. Phil Astrid S. 1974. Komunikasi dalam Teori dan Praktek I. Binacipta.

Wrahatnala, Bondet. 2012. Angket atau Kuesioner (Questionnaires). Diakses pada tanggal 26 Desember 2014. http://ssbelajar.blogspot.com/2012/11/angket-atau- kuesioner-questionaire.html.

Wuryanto, Agus. 2010. Prinsip Pendekatan Metode Tehnik Strategi dan Model Pembelajaran. Diakses pada tanggal 23 Desember 2014. https://aguswuryanto.wordpress.com/2010/07/20/prinsippendekatan-metode-teknik-strategi-dan-model-pembelajaran/ 